\title{
REGULAR ARTICLE \\ EFFECT OF CHROMIUM ON GROWTH AND YIELD OF VIGNA MUNGO (L.)
}

\author{
P. SUNDARAMOORTHY ${ }^{*}$, A. K. MURUGAN ${ }^{1}$, K. SANKAR GANESH ${ }^{2}$
}

${ }^{1}$ Department of Botany, Annamalai university Annamalai Nagar 608002, Tamil Nadu, India,

${ }^{2}$ Department of Botany, Government Arts College (Autonomous), Kumbakonam, India

\begin{abstract}
This study was conducted to find out the effect of different concentrations (control 5, 10, 25, 50, 100 and $200 \mathrm{mg} / \mathrm{l}$ ) of chromium on growth, yield of black gram (Vigna mungo L.). Pot culture experiments were carried out with black gram seeds with different concentrations of chromium solution. The morphological growth parameters were recorded at 15, 30, 45 and 60 $\mathrm{d}$ old chromium treated plants. The yield was recorded at the time of harvest. The study revealed that, the increase in chromium reduce the growth and yield in black gram plants.
\end{abstract}

Keywords: Chromium, Morphological, Biochemical, Yield, Blackgram

\section{INTRODUCTION}

Rapid industrialization has contributed all kinds of pollution in the environment including water pollution due to discharge of untreated industrial effluent containing heavy metals [1]. These heavy metal contaminated polluted water is being used for the irrigation in some dry areas. Heavy metal pollution has become very acute and is considered to be hazardous [2]. Among the heavy metals, chromium plays a major role in polluting the environment. There are two predominant forms of chromium, namely trivalent and hexavalent chromium. The wastewater released from chemical industries, chrome planting, textile, dye manufacturing, ink and pigment units, photographic material plants contained hexavalent chromium [3].

In India there are more than 2,500 tanneries in India with an annual processing capability of 5, oo,00o tonnes of hides and skin per year. About $80 \%$ of tanneries use chromium to the extent of 40,000 tonnes per year and about 15,000 tonnes go as waste in water streams [4]. In addition to leather tannery, there are many industries which contribute heavy metal pollution [5]. Numerous works have already been made on the impact of chromium on various plants under laboratory conditions [6-8]. But, the research work of chromium on growth and yield response of crops is very meagre. Black gram is one among the important legume crop cultivated throughout India [9]. So, an attempt has been made to examine the impact of various concentrations of chromium on growth, and yield parameters of blackgram (Vigna mungo L.) through pot culture experiments.

\section{MATERIALS AND METHODS}

The seeds of blackgram (Vigna mungo L.) were procured from Tamilnadu Agriculture Rice Research Institute, Aduthurai, Tanjore district of Tamilnadu. The earthern pots were lined with polythene sheets and filled with $5 \mathrm{~kg}$ of well mixed garden soil. The seeds were surface sterilized with $0.2 \% \mathrm{HgCl}_{2}$ solution and they were sown in the pots. The different concentrations $(10,25,50,100$ and 200 $\mathrm{mg} / \mathrm{l}$ ) of chromium were prepared from stock solution and used for irrigation. The set irrigated with bore-well water is treated as control. The experiment was replicated 3 times including control. The plant samples were collected at 15 , 30, 45 and $60 \mathrm{~d}$ after sowing and they were used for recording the various morphological growth parameters viz., plant height, total leaf area [10] and plant dry weight. The yield parameters such as number of pods per plant, number of seeds per pod and 100 seed weight were also recorded at the end of the experiment.

\section{RESULTS AND DISCUSSION}

The effect of different concentrations of chromium on plant height, total leaf area and plant dry weight of blackgram were recorded at 15, 30, 45 and $60 \mathrm{~d}$ after sowing (table 1). In this pot culture experiment, the maximum growth of black gram plants was observed at control plants and the minimum growth was observed at $200 \mathrm{mg} / \mathrm{l}$ chromium concentrations. The increase in chromium concentrations decreased all morphological growth parameters at all the sampling days. The reduction in growth parameters was observed from $5 \mathrm{mg} / \mathrm{l}$ concentration onwards. But $5 \mathrm{mg} / \mathrm{l}$ concentrations treated plants got higher results between the treatments. Similar findings were noted in various crops such as pea [11-13],

Received 22 March 2018; Accepted 19 April 2018

*Corresponding Author

P. Sundaramoorthy

Department of Botany, Annamalai university Annamalai Nagar 608002, Tamil Nadu, India

Email: ppsmoorthy@yahoo.com

(T) This article is open access and licensed under the terms of the Creative Commons Attribution License (http://creativecommons.org/licenses/by/4.o/) which permits unrestricted, use, distribution and reproduction in any medium, or format for any purpose, even commercially provided the work is properly cited. Attribution - You must give appropriate credit, provide a link to the license, and indicate if changes were made. 
cowpea [14] and tomato and brinjal [15]. The decreased root growth in higher concentrations of chromium treated plant may be due to inability of cells to divide or expand under heavy metal toxicity [16].

The reduction in plant growth may also be due to the formation of complex between metal and protein which inhibits protein synthesis and ultimately restricts the plant growth [17]. The decline in fresh weight and dry weight of plants at later stages of its growth is mainly due to the senescence of leaves. Further, the decline in fresh weight and dry weight of plants mainly due to degradation of root as well as reduction of new root formation [14]. There was a decrese in total leaf area under chromium irrigation. This may be due to reduction incell size [15]. Vazques et al. [18] also states that the variation in size of areoles is another feature which was markedly affected by different concentrations of chromium. The size of the areoles decreased in plants treated with chromium and this may be due to the decrease in the leaf area.

The yield of blackgram under chromium stress were shown in table 3. A gradual decline in all the yield parameters were observed at higher chromium concentrations. Similar findings of reduction in yield was observed in earlier reports $[12,13,19]$. It is also reported that the negative effect of yield and dry matter is essentially an indirect effect of chromium on plants higher concentrations of chromium reduced the growth and yield of blackgram as chromium is toxic to plants even a lower concentration.
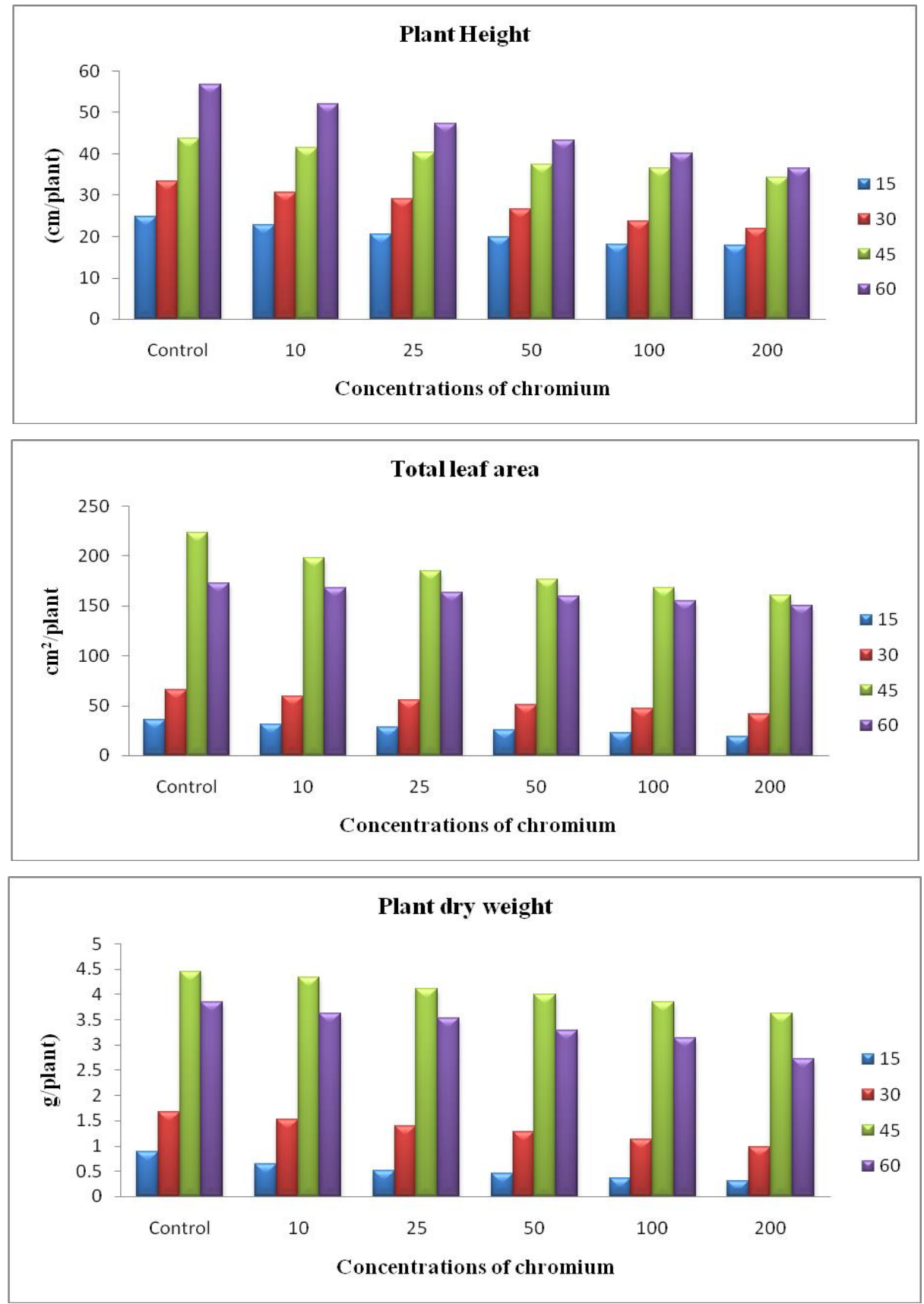

Fig. 1: Effect of different concentrations of chromium on plant height $(\mathrm{cm} / \mathrm{plant})$, total leaf area $\left(\mathrm{cm}^{2} / \mathrm{plant}\right)$ and plant dry weight (g/plant) of Blackgram (Vigna mungo L.) at different stages of its growth 

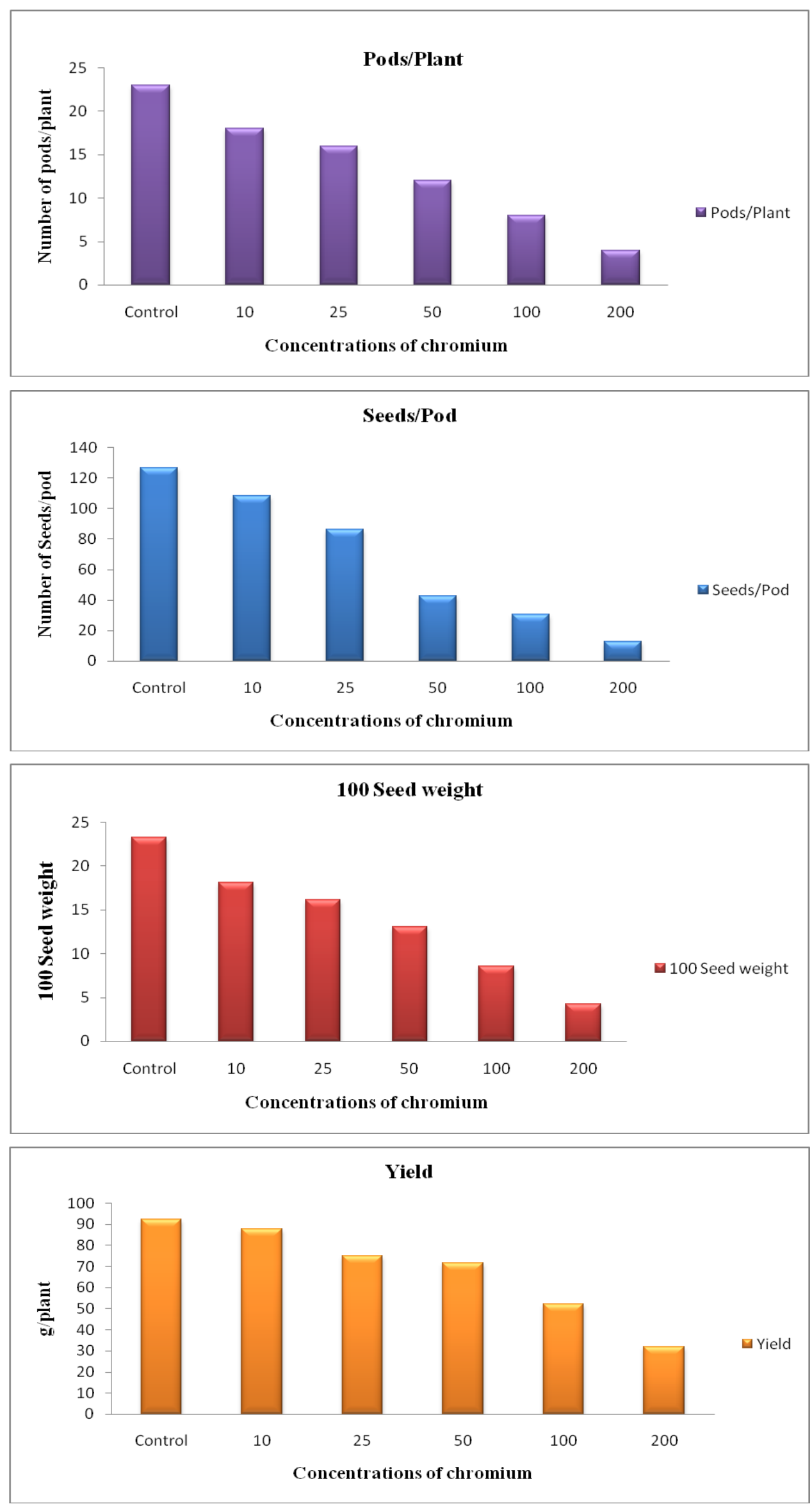

Fig. 2: Effect of different concentrations of chromium on yield parameters of Blackgram, (Vigna mungo L.) 
Table 1: Effect of different concentrations of chromium on plant height $(\mathrm{cm} / \mathrm{plant})$, total leaf area $\left(\mathrm{cm}^{2} / \mathrm{plant}\right)$ and plant dry weight (g/plant) of blackgram (Vigna mungo L.) at different stages of its growth

\begin{tabular}{|c|c|c|c|c|c|c|c|c|c|c|c|c|}
\hline \multirow{3}{*}{$\begin{array}{l}\text { Chromi } \\
\text { um } \\
\text { concent } \\
\text { rations } \\
(\mathrm{mg} / \mathrm{l})\end{array}$} & \multicolumn{12}{|c|}{ Age of the plant in days } \\
\hline & \multicolumn{3}{|c|}{15} & \multicolumn{3}{|l|}{30} & \multicolumn{3}{|l|}{45} & \multicolumn{3}{|l|}{60} \\
\hline & $\begin{array}{l}\text { Plant } \\
\text { height }\end{array}$ & $\begin{array}{l}\text { Total } \\
\text { leaf } \\
\text { area } \\
\end{array}$ & $\begin{array}{l}\text { Plant } \\
\text { dry } \\
\text { weight }\end{array}$ & $\begin{array}{l}\text { Plant } \\
\text { height }\end{array}$ & $\begin{array}{l}\text { Total } \\
\text { leaf } \\
\text { area }\end{array}$ & $\begin{array}{l}\text { Plant } \\
\text { dry } \\
\text { weight }\end{array}$ & $\begin{array}{l}\text { Plant } \\
\text { height }\end{array}$ & $\begin{array}{l}\text { Total } \\
\text { leaf } \\
\text { area } \\
\end{array}$ & $\begin{array}{l}\text { Plant } \\
\text { dry } \\
\text { weight }\end{array}$ & $\begin{array}{l}\text { Plant } \\
\text { height }\end{array}$ & $\begin{array}{l}\text { Total } \\
\text { leaf } \\
\text { area }\end{array}$ & $\begin{array}{l}\text { Plant } \\
\text { dry } \\
\text { weight }\end{array}$ \\
\hline Control & $\begin{array}{l}24.7 \\
\pm 0.93\end{array}$ & $\begin{array}{l}35.5 \pm \\
1.775\end{array}$ & $\begin{array}{l}0.8864 \\
\pm 0.035\end{array}$ & $\begin{array}{l}33.3 \\
\pm 1.332\end{array}$ & $\begin{array}{l}65.8 \pm \\
3.290\end{array}$ & $\begin{array}{l}1.666 \\
\pm 0.083\end{array}$ & $\begin{array}{l}43.8 \\
\pm 1.752\end{array}$ & $\begin{array}{l}223.2 \pm \\
11.160\end{array}$ & $\begin{array}{l}4.453 \\
\pm 0.178\end{array}$ & $\begin{array}{l}56.7 \\
\pm 2.83\end{array}$ & $\begin{array}{l}172.5 \pm \\
8.625\end{array}$ & $\begin{array}{l}3.850 \\
\pm 0.192\end{array}$ \\
\hline 10 & $\begin{array}{l}22.8 \\
\pm 1.14\end{array}$ & $\begin{array}{l}31.2 \pm \\
1.560\end{array}$ & $\begin{array}{l}0.6378 \\
\pm 0.019\end{array}$ & $\begin{array}{l}30.6 \\
\pm 1.53\end{array}$ & $\begin{array}{l}59.7 \pm \\
2.985\end{array}$ & $\begin{array}{l}1.528 \\
\pm 0.076\end{array}$ & $\begin{array}{l}41.4 \\
\pm 1.987\end{array}$ & $\begin{array}{l}198.5 \pm \\
9.925\end{array}$ & $\begin{array}{l}4.344 \\
\pm 0.217\end{array}$ & $\begin{array}{l}52.7 \\
\pm 2.63\end{array}$ & $\begin{array}{l}168.2 \pm \\
8.410\end{array}$ & $\begin{array}{l}3.628 \\
\pm 0.181\end{array}$ \\
\hline 25 & $\begin{array}{l}20.5 \\
\pm 0.82\end{array}$ & $\begin{array}{l}28.4 \pm \\
1.402\end{array}$ & $\begin{array}{l}0.5186 \\
\pm 0.025\end{array}$ & $\begin{array}{l}29.0 \\
\pm 0.92\end{array}$ & $\begin{array}{l}55.1 \pm \\
2.755\end{array}$ & $\begin{array}{l}1.400 \\
\pm 0.070\end{array}$ & $\begin{array}{l}40.3 \\
\pm 2.015\end{array}$ & $\begin{array}{l}185.2 \pm \\
9.260\end{array}$ & $\begin{array}{l}4.110 \\
\pm 0.205\end{array}$ & $\begin{array}{l}47.4 \\
\pm 1.89\end{array}$ & $\begin{array}{l}163.8 \pm \\
8.190\end{array}$ & $\begin{array}{l}3.534 \\
\pm 0.176\end{array}$ \\
\hline 50 & $\begin{array}{l}19.8 \\
\pm 0.99\end{array}$ & $\begin{array}{l}25.6 \pm \\
1.250\end{array}$ & $\begin{array}{l}0.4531 \\
\pm 0.022\end{array}$ & $\begin{array}{l}26.6 \\
\pm 1.33\end{array}$ & $\begin{array}{l}50.8 \pm \\
2.540\end{array}$ & $\begin{array}{l}1.284 \\
\pm 0.064\end{array}$ & $\begin{array}{l}37.5 \\
\pm 1.875\end{array}$ & $\begin{array}{l}176.8 \pm \\
8.840\end{array}$ & $\begin{array}{l}3.995 \\
\pm 0.199\end{array}$ & $\begin{array}{l}43.3 \\
\pm 1.73\end{array}$ & $\begin{array}{l}159.5 \pm \\
7.975\end{array}$ & $\begin{array}{l}3.294 \\
\pm 0.164\end{array}$ \\
\hline 100 & $\begin{array}{l}18.1 \\
\pm 0.90\end{array}$ & $\begin{array}{l}22.5 \pm \\
1.125\end{array}$ & $\begin{array}{l}0.3580 \\
\pm 0.017\end{array}$ & $\begin{array}{l}23.7 \\
\pm 1.18\end{array}$ & $\begin{array}{l}46.8 \pm \\
2.320\end{array}$ & $\begin{array}{l}1.126 \\
\pm 0.056\end{array}$ & $\begin{array}{l}36.4 \\
\pm 1.820\end{array}$ & $\begin{array}{l}168.2 \pm \\
8.410\end{array}$ & $\begin{array}{l}3.853 \\
\pm 0.192\end{array}$ & $\begin{array}{l}40.0 \\
\pm 2.20\end{array}$ & $\begin{array}{l}155.4 \pm \\
7.770\end{array}$ & $\begin{array}{l}3.138 \\
\pm 0.156\end{array}$ \\
\hline 200 & $\begin{array}{l}17.9 \\
\pm 0.89\end{array}$ & $\begin{array}{l}19.1 \pm \\
0.955\end{array}$ & $\begin{array}{l}0.3061 \\
\pm 0.015\end{array}$ & $\begin{array}{l}21.8 \\
\pm 1.09 \\
\end{array}$ & $\begin{array}{l}41.2 \pm \\
2.060\end{array}$ & $\begin{array}{l}0.980 \\
\pm 0.049\end{array}$ & $\begin{array}{l}34.3 \\
\pm 1.715 \\
\end{array}$ & $\begin{array}{l}160.2 \pm \\
8.010\end{array}$ & $\begin{array}{l}3.621 \\
\pm 0.181 \\
\end{array}$ & $\begin{array}{l}36.6 \\
\pm 1.83 \\
\end{array}$ & $\begin{array}{l}150.7 \pm \\
7.535\end{array}$ & $\begin{array}{l}2.733 \\
\pm 0.136\end{array}$ \\
\hline
\end{tabular}

\pm Standard deviation

Table 2: Effect of different concentrations of chromium on yield parameters of blackgram (Vigna mungo (L.) Hepper)

\begin{tabular}{|c|c|c|c|c|}
\hline \multirow{2}{*}{$\begin{array}{l}\text { Chromium concentrations } \\
\left(\mathrm{mg} \mathrm{l}^{-1}\right)\end{array}$} & \multicolumn{4}{|l|}{ Yield parameters } \\
\hline & Number of pods/plant & Number of seeds/pod & 10o seed weight & $\begin{array}{l}\text { Yield } \\
\text { (g/plant) }\end{array}$ \\
\hline Control & $23.0 \pm 1.15$ & $126.5 \pm 6.32$ & $23.28 \pm 1.16$ & $92.25 \pm 14.61$ \\
\hline 10 & $18.0 \pm 0.9$ & $108.2 \pm 5.41$ & $18.16 \pm 0.90$ & $87.8 \pm 4.39$ \\
\hline 25 & $16.0 \pm 0.8$ & $86.0 \pm 4.30$ & $16.15 \pm 0.80$ & $75.2 \pm 3.76$ \\
\hline 50 & $12.0 \pm 0.6$ & $42.50 \pm 2.12$ & $13.01 \pm 0.65$ & $71.7 \pm 3.58$ \\
\hline 100 & $8.0 \pm 0.40$ & $30.60 \pm 1.53$ & $8.60 \pm 0.43$ & $52.12 \pm 2.60$ \\
\hline 200 & $4.0 \pm 0.20$ & $12.80 \pm 0.64$ & $4.28 \pm 0.21$ & $32.0 \pm 1.60$ \\
\hline
\end{tabular}

\pm Standard deviation

\section{CONCLUSION}

From this study, it is concluded that the higher concept of Chromium reduced the growth and yield of Blackgram low concentration. It should be removed from the irrigated water. The industrial wastewaters with heavy metals should be treated fully before they discharged into the environment. Both the government and the industries should involve themselves in the environmental protection.

\section{ACKNOWLEDGEMENT}

The authors are thankful to Professor and Head, Department of Botany, Annamalai University for providing laboratory facilities.

\section{REFERENCES}

1. Förstner U, Wittmann GT. Metal pollution in the aquatic environment. Springer Science and Business Media; 2012 Dec 6.

2. Järup L. Hazards of heavy metal contamination. British medical bulletin. 2003;68:167-82.

3. Dhal B, Thatoi HN, Das NN, Pandey BD. Chemical and microbial remediation of hexavalent chromium from contaminated soil and mining/metallurgical solid waste: a review. Journal of hazardous materials. 2013;250:272-91.

4. Rajamani, S. 1995. Central chrome recovery and reuse system for a cluster of small sacle tanneries in India. Paper presented at LERIS'95 held at CLRI, Chennai.

5. Ghosh, M. and Singh, S. P. 2000. Comparative uptake and phytoextraction study of soil induced chromium by accumulator and high biomass weed species. Applied Ecology and Environment Research, 3: 67-79.

6. Pandit, B. R. and Prasannakumar, P. G. 1999. Effect of metals on jowar (Sorghum bicolour L.) seedling growth-I. Germination, seedling growth and absorption of elements. Poll. Res., 15: 459-466.

7. Lakshmi, S. and Sundaramoorthy, P. 2003. Effect of chromium on germination and biochemical changes in blackgram. J. Ecobiol., 15: 1-11.

8. Samantaray, S. and Deo, B. 2004. Studies on chromium toxicity in mungbean (Vigna radiata L.). Ad. Plant Sci., 17: 129-134.

9. Poehlman, J. M., 1991. The Mung bean. Oxford and IBH Publishing Co., New Delhi.

10. Kalra, G. S. and Dhiman, SD 1977. Determination of leaf area of wheat plants by a rapid method. J. Indian. Bot. Soc., 56:261-264.

11. Bishnoi, N. R., Chugh, L. K. and Sawhney, S. K. 1993. Effect of chromium on photosynthesis, respiration and nitrogen fixation in pea (Pisum sativum) seedlings. J. Plant Physiol., 142:25-30.

12. Sharma, D. C. and Mehrotra, S. C. 1993. Chromium toxicity effects on wheat (Triticum aestivum L cv. HD 2204). Indian J. Environ Health, 35:330-332.

13. Sharma, D. C. and Sharma, C. P. 1993. Chromium uptake and its effects on growth and biological yield of wheat. Cereal Res Commun., 21:317-321.

14. Joshi, U. N, Rathore, S. S. and Arora, S. K. 1999. Effect of chromium on growth and development of cowpea (Vigna unguiculata L.). Ind. J. Environ. Prot., 19: $745-749$. 
15. Purohoit, S., Varghese, T. M. and Kumari, M. 2003. Effect of chromium on morphological features of tomato and brinjal. Indian J. Plant Physiol., 8: 17-22.

16. Barcelo, J., Poschenrieder, C., Gunse, B. 1986. Water relations of chromium VI treated bush bean plants (Phaseolus vulgaris L. cv. Contender) under both normal and water stress conditions. J. Exp. Bot., 37:178-187.
17. Foy, C. D., Duke, R. L. and Devine, T. E., 1992. Tolerance of soybean germplasm to an acid tatum subsoil. J. Plant nutrition, 15:527-547.

18. Vazques, M. D., Poschenrider, Ch. and Barcelo, J. 1987. Chromium (VI) induced structural changes in bush bean plants. Ann Bot., 59:427-438

19. Shanker, A. K., Cervantes, C., Tavera, H. L. and Avudainayagam, S. 2005. Chromium toxicity in plants. Environment International, 31:739-753. 